Archives of Agriculture and Environmental Science

\title{
Effects of plant spacing and nitrogen level on the green fodder yield of maize (Zea mays L.)
}

\author{
Newton Chandra Paul, Uttam Paul, Shabuj Chandra Paul and Swapan Kumar Paul* (D)
}

Department of Agronomy, Bangladesh Agricultural University, Mymensingh - 2202, BANGLADESH

*Corresponding author's Email:skpaul@bau.edu.bd

\section{ARTICLE HISTORY}

Received: 18 August 2019

Revised received: 26 August 2019

Accepted: 06 September 2019

\section{Keywords}

Green fodder

Maize

Nitrogen levels

Plant spacing

Yield

\section{ABSTRACT}

An experiment was conducted at the Agronomy Field Laboratory, Bangladesh Agricultural University, Mymensingh during December 2016 to February 2017 to investigate the effect of plant spacing and nitrogen level on growth parameters and green fodder yield of maize (Zea mays L.). The experiment comprised three plant spacings viz., $35 \mathrm{~cm} \times 10 \mathrm{~cm}, 35 \mathrm{~cm} \times 20 \mathrm{~cm}, 35$ $\mathrm{cm} \times 30 \mathrm{~cm}$ and three nitrogen levels viz., 100,150 and $200 \mathrm{~kg} \mathrm{~N} \mathrm{ha}^{-1}$. The experiment was laid out in a randomized complete block design with three replications. Results revealed that plant spacing, nitrogen levels and their interaction had significant effect on growth parameters and green fodder yield. The tallest plant $(192.5 \mathrm{~cm})$ was obtained at plant spacing $35 \mathrm{~cm} \times 30 \mathrm{~cm}$, while the highest fodder yield $\left(61.13 \mathrm{t} \mathrm{ha}^{-1}\right)$ of $Z$. mays was recorded at $35 \mathrm{~cm} \times 10 \mathrm{~cm}$ spacing. In case of nitrogen level, the tallest plant $(204.9 \mathrm{~cm})$, the highest number of leaves plant $^{-1}$ (12.22), the highest chlorophyll content in leaves (41.50) and the highest fodder yield (70.38 $\mathrm{t} \mathrm{ha}^{-1}$ ) of $Z$. mays were recorded in $200 \mathrm{~kg} \mathrm{~N} \mathrm{ha}^{-1}$. In case of interaction, the tallest plant $\left(218.4 \mathrm{~cm}\right.$ ) of Z. mays was produced at spacing $35 \mathrm{~cm} \times 30 \mathrm{~cm}$ along with $200 \mathrm{~kg} \mathrm{~N} \mathrm{ha}^{-1}$. The highest fodder yield $\left(78.01 \mathrm{t} \mathrm{ha}^{-1}\right)$ of Z. mays was obtained at spacing $35 \mathrm{~cm} \times 10 \mathrm{~cm}$ fertilized with $200 \mathrm{~kg} \mathrm{~N} \mathrm{ha}^{-1}$ which was at par with spacing $35 \mathrm{~cm} \times 20 \mathrm{~cm}$ fertilized with $200 \mathrm{~kg} \mathrm{~N} \mathrm{ha}^{-1}$ and the lowest fodder yield $\left(31.91 \mathrm{t} \mathrm{ha}^{-1}\right)$ was obtained at spacing $35 \mathrm{~cm} \times 30 \mathrm{~cm}$ along with $100 \mathrm{~kg} \mathrm{~N} \mathrm{ha}^{-1}$. Therefore, spacing $35 \mathrm{~cm} \times 10 \mathrm{~cm}$ fertilized with $200 \mathrm{~kg} \mathrm{~N} \mathrm{ha}^{-1}$ appears as the promising practice for maize cultivation as fodder crop.

(C)2019 Agriculture and Environmental Science Academy

Citation of this article: Paul, N.C., Paul, U., Paul, S.C. and Paul, S.K. (2019). Effects of plant spacing and nitrogen level on the green fodder yield of maize (Zea mays L.). Archives of Agriculture and Environmental Science, 4(3): 307-312, https://dx.doi.org/10.26832/24566632.2019.040308

\section{INTRODUCTION}

Maize (Zea mays L.) is used as multipurpose crop such as food, feed, and fodder crop in Bangladesh. Maize is a very convenient crop for fodder production due to the high production of green mass per unit area, high energy content of dry matter and quality of biomass for silage (Mandić et al., 2013). It is extensively grown in temperate, subtropical and tropical regions of the world throughout the year mainly due to its photo-thermoinsensitive character (Verma, 2011). In Bangladesh, it can be grown in both Rabi and Kharif season. The cultivation of maize has been gaining popularity in the recent years for its high productivity and diversified use in Bangladesh (Tajul et al.,
2013). Maize crop has been included as a major enterprise in the crop diversification and intensive cropping programmes (Zamir et al., 2011). Although the soil and climatic conditions of Bangladesh are favorable for the maize production, but it's per $\mathrm{ha}^{-1}$ fodder yield is very low as compared to other country of the world. Low yield of maize was due to many agronomic factors, but plant spacing and nitrogenous fertilizer application is considered most important factors which can increase fodder production significantly. Among the agronomic practices that influence crop growth and seed yield, plant spacing and fertilizer management are the prominent ones. Competition associated with different spacing alters plant morphology in various ways. As such there is a considerable scope for increasing yield 
by adjusting optimum plant spacing. High density is undesirable because it encourages inter-plant competition for resources while resource will simply be misuse under sparse plant spacing (Salam et al., 2010).

Nitrogen is a primary nutrient required by crop plants for their growth and development. Nitrogen plays an important role in building up of protoplast and protein, which induce cell division and initiate epistemic activities when applied in optimum quantity. The application of nitrogen not only affects the forage yield of maize, but also improves its quality especially its protein contents (Haque et al., 2001). It is reported that application of nitrogen to maize increase fodder nutritive value by increasing crude protein and by reducing ash and fiber contents. Study on nitrogen management and spacing would enrich the knowledge on development of management tools for higher fodder yield per unit area of this crop. This study was therefore, undertaken to determine the optimum spacing and nitrogen fertilizer on growth and fodder yield of maize (Zea mays L.).

\section{MATERIALS AND METHODS}

\section{Experimental sites and experimentation}

The experiment was carried out at the Agronomy Field Laboratory, Department of Agronomy, Bangladesh Agricultural University, Mymensingh during December 2016 to February 2017. The experiment site located at $24^{\circ} 75^{\prime} \mathrm{N}$ latitude and $90^{\circ}$ $50^{\prime} \mathrm{E}$ longitude having an altitude of $18 \mathrm{~m}$ above the mean sea level. The experimental site belongs to the Sonatala series of Old Brahmaputra Floodplain Agro ecological Zone (AEZ-9) having non-calcareous dark grey floodplain soils (UNDP and FAO, 1998). The experiment was done in a randomized complete block design with three replications having three plant spacings viz., $35 \mathrm{~cm} \times 10 \mathrm{~cm}, 35 \mathrm{~cm} \times 20 \mathrm{~cm}, 35 \mathrm{~cm} \times 30 \mathrm{~cm}$ and three nitrogen levels viz., 100,150 and $200 \mathrm{~kg} \mathrm{~N} \mathrm{ha}^{-1}$. The size of each unit plot was $2.5 \mathrm{~m} \times 2.0 \mathrm{~m}$. The land was fertilized with triple super phosphate (TSP), muriate of potash (MoP), gypsum and zinc sulphate @ 270 kg, 220 kg, 220 kg and $15 \mathrm{~kg} \mathrm{ha}^{-1}$, respectively. Nitrogen was applied in the form of prilled urea as per treatment of the experiment in three equal splits. Onethird of the urea and entire amount of triple super phosphate, muriate of potash, gypsum and zinc sulphate were applied at final land preparation and the remaining urea was applied in two equal splits at 20 and 50 days after sowing (DAS). Rows were oriented length wise in north-south direction. Seeds of Z. mays were sown on 5 December 2016 as per experimental spacing apart by opening 3-4 cm deep furrows with tine. BARI developed maize cultivar BARI hybrid maize 9 was used as test crop. Two seeds were sown in each hill ${ }^{-1}$. Weeding was done at 15 and 30 DAS. Only one healthy seedling hill $^{-1}$ was kept and the rest were thinned out at 15 DAS (at the time of first weeding). The crop of Z. mays was irrigated two times at 20 and 50 DAS after topdressing of urea.

\section{Data collection}

Five plants were randomly with bamboo sticks in each plot excluding border rows to record the data on vegetative characters. Chlorophyll meter values (SPAD) were recorded using a portable SPAD meter (Model SPAD-502, Minolta crop, Ramsey, $\mathrm{NJ})$. The instrument measures transmission of red light at 650 $\mathrm{nm}$, at which chlorophyll absorbs light and transmission of infrared light at $940 \mathrm{~nm}$, at which no absorption occurs. The chlorophyll meter readings have been positively correlated with destructive chlorophyll measurements in many crop species (Zhu et al., 2012) and considered as a useful indicator of the need of $\mathrm{N}$ top dressing during the crop growth on the basis of these two transmission values, the instrument calculates a SPAD value that is well correlated with chlorophyll content (Paul et al., 2018). At silking and milk stage (of the grain), the crop was harvested plot-wise and converted into $\mathrm{tha}^{-1}$.

\section{Statistical analysis}

The collected data were statistically analyzed using "Analysis of Variance" technique with the help of computer program, MSTAT. Mean differences among the treatments were adjudged by using the Duncun's Multiple Range Test (DMRT) (Gomez and Gomez, 1984).

\section{RESULTS AND DISCUSSION}

\section{Plant height of Z. mays}

Plant height of Z. mays was significantly influenced by plant spacing at 30 DAT and at harvest. At 30 DAT, the tallest plant $(68.06 \mathrm{~cm})$ was obtained in $35 \mathrm{~cm} \times 30 \mathrm{~cm}$ plant spacing, which was statistically identical to spacing $35 \mathrm{~cm} \times 10 \mathrm{~cm}$ and the shortest plant $(62.64 \mathrm{~cm})$ was obtained in $35 \mathrm{~cm} \times 20 \mathrm{~cm}$ plant spacing (Table 1). At 45 DAT, numerically the tallest plant $(91.89$ $\mathrm{cm}$ ) of Z. mays was obtained in $35 \mathrm{~cm} \times 30 \mathrm{~cm}$ spacing and the shortest plant $(87.03 \mathrm{~cm})$ of Z. mays was obtained at spacing 35 $\mathrm{cm} \times 10 \mathrm{~cm}$ (Table 1). At harvest, the tallest plant $(192.5 \mathrm{~cm})$ of $Z$. mays was obtained in spacing $35 \mathrm{~cm} \times 30 \mathrm{~cm}$ followed by $35 \mathrm{~cm} \times$ $20 \mathrm{~cm}$ spacing and the shortest one $(158.3 \mathrm{~cm})$ of Z. mays was obtained at $35 \mathrm{~cm} \times 10 \mathrm{~cm}$ plant spacing (Table 1). Nitrogen fertilization has significant influence on plant height at 30, 45 DAT and at harvest. At 30 DAT, the tallest plant $(70.89 \mathrm{~cm})$ was obtained in $200 \mathrm{~kg} \mathrm{~N} \mathrm{ha}^{-1}$, which was statistically identical to $150 \mathrm{~kg} \mathrm{~N} \mathrm{ha}^{-1}$ and the shortest on $(58.75 \mathrm{~cm})$ was obtained when fertilized with $100 \mathrm{~kg} \mathrm{~N}^{-1}$ (Table 2). At $45 \mathrm{DAT}$, the tallest plant $(100.6 \mathrm{~cm})$ of Z. mays was obtained in $200 \mathrm{~kg} \mathrm{~N}^{-1}$ followed by $150 \mathrm{~kg} \mathrm{~N} \mathrm{ha}^{-1}$ and the shortest plant $(81.44 \mathrm{~cm})$ of $Z$. mays was obtained in $100 \mathrm{~kg} \mathrm{~N} \mathrm{ha}^{-1}$ (Table 2). At harvest, the tallest plant $(204.9 \mathrm{~cm})$ of Z. mays was obtained from $200 \mathrm{~kg} \mathrm{~N}$ $\mathrm{ha}^{-1}$ followed by $150 \mathrm{~kg} \mathrm{~N} \mathrm{ha}^{-1}$ and the shortest plant $(155.4 \mathrm{~cm})$ of Z. mays was obtained from $100 \mathrm{~kg} \mathrm{~N}^{-1}$ (Table 2). Plant height was increased significantly with increase nitrogen levels were reported by Ullah et al. (2015) and Khan et al. (2014). The interaction between plant spacing and nitrogen fertilization has significant influence on plant height at 30, 45 DAT and at harvest. At 30 DAT, the tallest plant $(72.08 \mathrm{~cm})$ of Z. mays was obtained at spacing $35 \mathrm{~cm} \times 20 \mathrm{~cm}$ fertilized with $200 \mathrm{~kg} \mathrm{~N} \mathrm{ha}^{-1}$, which was statistically identical to the plant spacing $35 \mathrm{~cm} \times 10$ 
$\mathrm{cm}$ fertilized with $200 \mathrm{~kg} \mathrm{~N}^{-1}$, spacing $35 \mathrm{~cm} \times 30 \mathrm{~cm}$ fertilized with $100 \mathrm{~kg} \mathrm{~N} \mathrm{ha}^{-1}$, spacing $35 \mathrm{~cm} \times 30 \mathrm{~cm}$ along with 150 $\mathrm{kg} \mathrm{N} \mathrm{ha}{ }^{-1}$ and plant spacing $35 \mathrm{~cm} \times 30 \mathrm{~cm}$ fertilized with $200 \mathrm{~kg}$ $\mathrm{N} \mathrm{ha}^{-1}$ and the shortest plant $(52.17 \mathrm{~cm})$ of Z. mays was obtained at the spacing $35 \mathrm{~cm} \times 20 \mathrm{~cm}$ along with $100 \mathrm{~kg} \mathrm{~N} \mathrm{ha}^{-1}$, which was statistically identical to spacing $35 \mathrm{~cm} \times 10 \mathrm{~cm}$ fertilized with $100 \mathrm{~kg} \mathrm{~N}^{-1}{ }^{-1}$ (Table 3). At 45 DAT, the tallest plant (103.3 $\mathrm{cm}$ ) was obtained from the spacing $35 \mathrm{~cm} \times 10 \mathrm{~cm}$ along with $200 \mathrm{~kg} \mathrm{~N} \mathrm{ha}^{-1}$, which was statistically identical to spacing $35 \mathrm{~cm}$ $\times 20 \mathrm{~cm}$ fertilized with $200 \mathrm{~kg} \mathrm{~N}^{-1}$, spacing $35 \mathrm{~cm} \times 30 \mathrm{~cm}$ along with $150 \mathrm{~kg} \mathrm{~N} \mathrm{ha}^{-1}$ and $35 \mathrm{~cm} \times 30 \mathrm{~cm}$ spacing along with $200 \mathrm{~kg} \mathrm{~N} \mathrm{ha}^{-1}$ and the shortest plant $(74.83 \mathrm{~cm})$ of Z. mays was obtained from spacing $35 \mathrm{~cm} \times 10 \mathrm{~cm}$ combined with $100 \mathrm{~kg} \mathrm{~N}$ $\mathrm{ha}^{-1}$, which was statistically identical to plant spacing $35 \mathrm{~cm} \times 10$ $\mathrm{cm}$ fertilized with $150 \mathrm{~kg} \mathrm{~N} \mathrm{ha}^{-1}, 35 \mathrm{~cm} \times 20 \mathrm{~cm}$ along with $100 \mathrm{~kg}$ $\mathrm{N} \mathrm{ha}^{-1}, 35 \mathrm{~cm} \times 20 \mathrm{~cm}$ fertilized with $150 \mathrm{~kg} \mathrm{~N} \mathrm{ha}^{-1}$ and $35 \mathrm{~cm} \times 30$ $\mathrm{cm}$ fertilized with $100 \mathrm{~kg} \mathrm{~N} \mathrm{ha}^{-1}$ (Table 3). At harvest, the tallest plant $(218.4 \mathrm{~cm})$ of $Z$. mays was obtained from the plant spacing $35 \mathrm{~cm} \times 30 \mathrm{~cm}$ fertilized with $200 \mathrm{~kg} \mathrm{~N} \mathrm{ha}^{-1}$, which was statistically identical to spacing $35 \mathrm{~cm} \times 20 \mathrm{~cm}$ along with $200 \mathrm{~kg} \mathrm{~N} \mathrm{ha}^{-1}$ and $35 \mathrm{~cm} \times 30 \mathrm{~cm}$ along with $150 \mathrm{~kg} \mathrm{~N} \mathrm{ha}^{-1}$ and the shortest plant $(128.8 \mathrm{~cm})$ of $Z$. mays was obtained at $35 \mathrm{~cm} \times 10 \mathrm{~cm}$ spacing along with $100 \mathrm{~kg} \mathrm{~N} \mathrm{ha}^{-1}$, which was statistically identical to

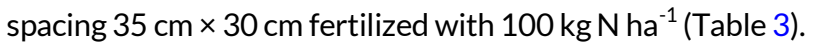

Table 1. Effect of plant spacing on vegetative characters of Z. mays as fodder crop.

\begin{tabular}{|c|c|c|c|c|c|c|}
\hline \multirow{3}{*}{ Planting Spacing } & \multicolumn{6}{|c|}{ Crop characters at different days after sowing } \\
\hline & \multicolumn{2}{|c|}{$30 \mathrm{DAS}$} & \multicolumn{2}{|c|}{45 DAS } & \multicolumn{2}{|c|}{ At harvest } \\
\hline & $\begin{array}{l}\text { Plant height } \\
\text { (cm) }\end{array}$ & $\begin{array}{c}\text { Number of } \\
\text { leaves plant }\end{array}$ & $\begin{array}{l}\text { Plant height } \\
\text { (cm) }\end{array}$ & $\begin{array}{c}\text { Number of leaves } \\
\text { plant }^{-1}\end{array}$ & $\begin{array}{l}\text { Plant height } \\
\text { (cm) }\end{array}$ & $\begin{array}{c}\text { Number of } \\
\text { leaves plant }{ }^{-1}\end{array}$ \\
\hline $35 \mathrm{~cm} \times 10 \mathrm{~cm}$ & $63.06 a b$ & $8.33 b$ & 87.03 & 9.67 & $158.3 c$ & 10.89 \\
\hline $35 \mathrm{~cm} \times 20 \mathrm{~cm}$ & $62.64 b$ & $8.44 a b$ & 90.08 & 9.89 & 187.3b & 11.44 \\
\hline $35 \mathrm{~cm} \times 30 \mathrm{~cm}$ & $68.06 a$ & $9.11 \mathrm{a}$ & 91.89 & 10.11 & $192.5 a$ & 11.11 \\
\hline $\mathrm{S}_{\overline{\mathrm{x}}}$ & 2.91 & 0.41 & 5.28 & 0.44 & 9.70 & 0.47 \\
\hline Level of significance & $*$ & * & NS & NS & $* *$ & NS \\
\hline CV (\%) & 7.80 & 8.38 & 10.21 & 7.72 & 9.37 & 7.37 \\
\hline
\end{tabular}

In a column, figures with same letter(s) or without letter do not differ significantly whereas figures with dissimilar letter differ significantly (as per DMRT), ${ }^{* *}=$ Significant at $1 \%$ level of probability, ${ }^{*}=$ Significant at $5 \%$ level of probability, NS $=$ Not significant.

Table 2. Effect of nitrogen level on vegetative characters of Z. mays as fodder crop.

\begin{tabular}{|c|c|c|c|c|c|c|}
\hline \multirow{3}{*}{$\begin{array}{l}\text { Level of nitrogen } \\
\left(\mathrm{kg} \mathrm{ha}^{-1}\right)\end{array}$} & \multicolumn{6}{|c|}{ Crop characters at different days after sowing } \\
\hline & \multicolumn{2}{|c|}{30 DAS } & \multicolumn{2}{|c|}{45 DAS } & \multicolumn{2}{|c|}{ At harvest } \\
\hline & $\begin{array}{l}\text { Plant height } \\
\text { (cm) }\end{array}$ & $\begin{array}{l}\text { Number of } \\
\text { leaves plant }\end{array}$ & $\begin{array}{l}\text { Plant height } \\
\text { (cm) }\end{array}$ & $\begin{array}{l}\text { Number of } \\
\text { leaves plant }\end{array}$ & $\begin{array}{l}\text { Plant height } \\
\text { (cm) }\end{array}$ & $\begin{array}{l}\text { Number of } \\
\text { leaves plant }\end{array}$ \\
\hline 100 & $58.75 c$ & 8.44 & $81.44 c$ & 9.53 & $155.4 c$ & $10.56 \mathrm{~b}$ \\
\hline 150 & $64.11 a b$ & 8.44 & $86.9 b$ & 9.56 & $177.8 \mathrm{~b}$ & $10.67 b$ \\
\hline 200 & $70.89 a$ & 9.00 & $100.6 a$ & 10.60 & $204.9 a$ & $12.22 \mathrm{a}$ \\
\hline $\mathrm{S}_{\overline{\mathrm{x}}}$ & 2.90 & 0.42 & 5.23 & 0.93 & 9.70 & 0.47 \\
\hline Level of significance & $* *$ & NS & ** & NS & $* *$ & * \\
\hline CV $(\%)$ & 7.80 & 8.38 & 10.21 & 7.72 & 9.37 & 7.37 \\
\hline
\end{tabular}

In a column, figures with same letter(s) or without letter do not differ significantly whereas figures with dissimilar letter differ significantly (as per DMRT), ${ }^{* *}=$ Significant at $1 \%$ level of probability, ${ }^{*}=$ Significant at $5 \%$ level of probability, $N S=$ Not significant. $N_{1}=100 \mathrm{~kg} / \mathrm{ha}, \mathrm{N}_{2}=150 \mathrm{~kg} / \mathrm{ha}, \mathrm{N}_{3}=200$ $\mathrm{kg} / \mathrm{ha}$.

Table 3. Effect of interaction between spacing and nitrogen level on vegetative characters of Z. mays as fodder crop.

\begin{tabular}{|c|c|c|c|c|c|c|c|}
\hline \multirow{3}{*}{ Planting Spacing } & \multirow{3}{*}{$\begin{array}{l}\text { Level of } \\
\text { nitrogen } \\
\left(\mathrm{kg} \mathrm{ha}^{-1}\right)\end{array}$} & \multicolumn{6}{|c|}{ Crop characters at different days after sowing } \\
\hline & & \multicolumn{2}{|c|}{30 DAS } & \multicolumn{2}{|c|}{45 DAS } & \multicolumn{2}{|c|}{ At harvest } \\
\hline & & $\begin{array}{c}\text { Plant } \\
\text { height }(\mathrm{cm})\end{array}$ & $\begin{array}{l}\text { Number of } \\
\text { leaves plant }\end{array}$ & $\begin{array}{l}\text { Plant height } \\
\text { (cm) }\end{array}$ & $\begin{array}{l}\text { Number of } \\
\text { leaves plant }\end{array}$ & $\begin{array}{l}\text { Plant height } \\
\text { (cm) }\end{array}$ & $\begin{array}{c}\text { Number of } \\
\text { leaves plant }{ }^{-1}\end{array}$ \\
\hline & 100 & $58.58 \mathrm{~cd}$ & 8.33 & $74.83 c$ & 9.33 & $128.8 \mathrm{e}$ & 10.00 \\
\hline \multirow[t]{3}{*}{$35 \mathrm{~cm} \times 10 \mathrm{~cm}$} & 150 & $59.67 c$ & 7.66 & $83.00 b c$ & 9.00 & $162.3 \mathrm{~cd}$ & 10.33 \\
\hline & 200 & $70.92 \mathrm{ab}$ & 9.00 & 103.3a & 10.67 & $183.8 \mathrm{bc}$ & 12.33 \\
\hline & 100 & $52.17 d$ & 8.33 & $81.83 b c$ & 9.33 & $185.3 \mathrm{bc}$ & 10.67 \\
\hline \multirow[t]{3}{*}{$35 \mathrm{~cm} \times 20 \mathrm{~cm}$} & 150 & $63.67 \mathrm{bc}$ & 8.33 & $85.50 b c$ & 10.00 & $164.2 \mathrm{~cd}$ & 11.33 \\
\hline & 200 & $72.08 a$ & 8.66 & $102.9 \mathrm{a}$ & 10.33 & 212.3ab & 12.33 \\
\hline & 100 & 65.50abc & 8.66 & $87.67 b c$ & 10.00 & 152.3de & 11.00 \\
\hline \multirow[t]{2}{*}{$35 \mathrm{~cm} \times 30 \mathrm{~cm}$} & 150 & 69.00ab & 9.33 & 92.33ab & 9.66 & $206.8 a b$ & 10.33 \\
\hline & 200 & 69.67ab & 9.33 & $95.67 a b$ & 10.67 & $218.4 a$ & 12.00 \\
\hline $\mathrm{S}_{\overline{\mathrm{x}}}$ & & 2.90 & 0.41 & 5.28 & 0.44 & 9.70 & 0.47 \\
\hline Level of significance & & $*$ & NS & $*$ & NS & $* *$ & NS \\
\hline CV (\%) & & 7.80 & 8.38 & 10.21 & 7.72 & 9.37 & 7.37 \\
\hline
\end{tabular}

In a column, figures with same letter(s) or without letter do not differ significantly whereas figures with dissimilar letter differ significantly (as per DMRT), ${ }^{* *}=$ Significant at $1 \%$ level of probability, ${ }^{*}=$ Significant at $5 \%$ level of probability, NS $=$ Not significant. 
Number of leaves plant ${ }^{-1}$ of $Z$. mays

Number of leaves plant $^{-1}$ was significantly influenced by plant spacing at 30 DAT. At 30 DAT, the highest number of leaves plant $^{-1}$ (9.11) of Z. mays was obtained at spacing $35 \mathrm{~cm} \times 30 \mathrm{~cm}$, which was statistically identical to $35 \mathrm{~cm} \times 20 \mathrm{~cm}$ spacing and the lowest number of leaves plant $^{-1}$ (8.33) of Z. mays was obtained at $35 \mathrm{~cm} \times 10 \mathrm{~cm}$ spacing (Table 1). At $45 \mathrm{DAT}$, numerically the highest number of leaves plant ${ }^{-1}(10.11)$ of Z. mays was obtained at spacing $35 \mathrm{~cm} \times 30 \mathrm{~cm}$ followed by $35 \mathrm{~cm} \times 20 \mathrm{~cm}$ spacing and the lowest number of leaves plant ${ }^{-1}$ (9.67) of $Z$. mays was obtained in $35 \mathrm{~cm} \times 10 \mathrm{~cm}$ spacing (Table 1). At final harvest, numerically the highest number of leaves plant ${ }^{-1}$ (11.44) of Z. mays was obtained at the spacing $35 \mathrm{~cm} \times 20 \mathrm{~cm}$ followed by $35 \mathrm{~cm} \times 30 \mathrm{~cm}$ spacing and the lowest number of leaves plant ${ }^{-1}$ (10.89) of Z. mays was obtained at $35 \mathrm{~cm} \times 10 \mathrm{~cm}$ spacing (Table 1). Lamana (2007) reported that the wider plant spacing had a positive effect on number of leaves plant ${ }^{-1}$. Nitrogen fertilization has significant influence on number of leaves plant ${ }^{-1}$ at harvest. At 30 DAT, numerically the highest number of leaves plant ${ }^{-1}$ (9.00) of Z. mays was obtained in 200 $\mathrm{kg} \mathrm{N} \mathrm{ha}^{-1}$ and the lowest number of leaves plant ${ }^{-1}$ (8.44) of $Z$. mays was obtained from $150 \mathrm{~kg} \mathrm{~N} \mathrm{ha}^{-1}$ and $100 \mathrm{~kg} \mathrm{~N} \mathrm{ha}^{-1}$ (Table 2). At 45 DAT, numerically the highest number of leaves plant ${ }^{-1}$ (10.60) of Z. mays was obtained in $200 \mathrm{~kg} \mathrm{~N} \mathrm{ha}^{-1}$ followed by 150 $\mathrm{kg} \mathrm{N} \mathrm{ha}^{-1}$ and the lowest number of leaves plant ${ }^{-1}$ (9.53) of $Z$. mays was obtained in $100 \mathrm{~kg} \mathrm{~N}^{-1}$ (Table 2). At harvest, the

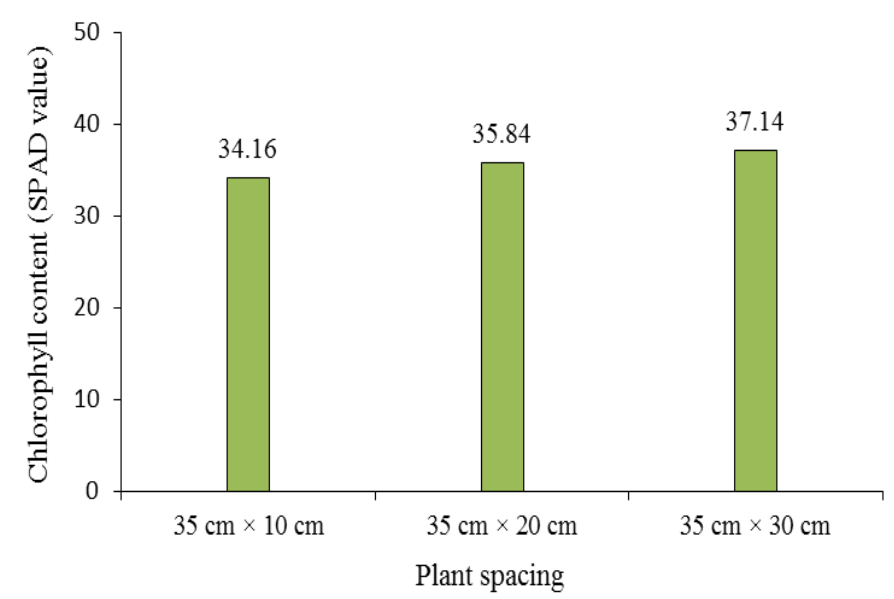

Figure 1. Effect of plant spacing on chlorophyll content of Z. mays as fodder crop.

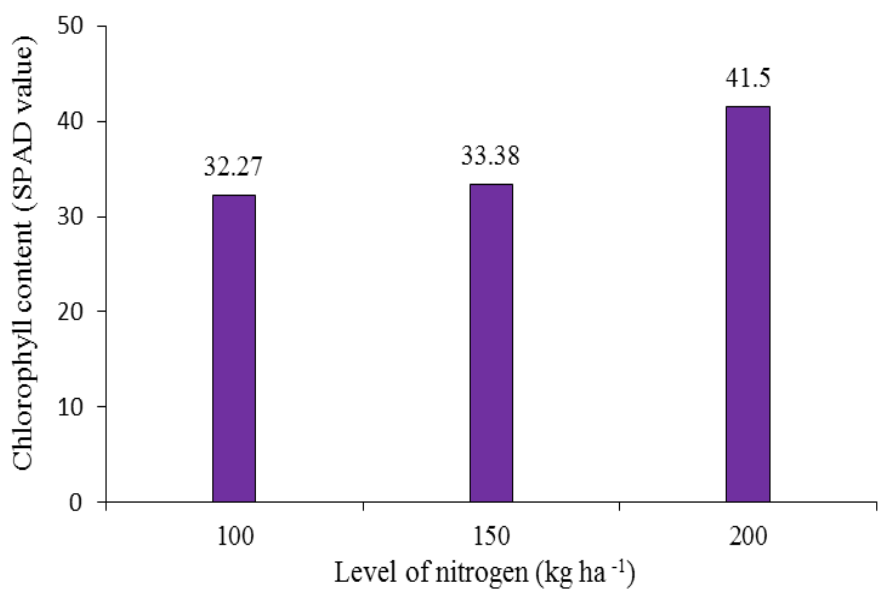

Figure 2. Effect of level of nitrogen on chlorophyll content of Z. mays as fodder crop. highest number of leaves plant ${ }^{-1}$ (12.22) of Z. mays was obtained from $200 \mathrm{~kg} \mathrm{~N} \mathrm{ha}^{-1}$ and the lowest number of leaves plant ${ }^{-1}$ (10.56) of Z. mays was obtained in $100 \mathrm{~kg} \mathrm{~N} \mathrm{ha}^{-1}$, which was statistically identical to $150 \mathrm{~kg} \mathrm{~N}^{-1}$ (Table 2). Number of leaves plant ${ }^{-1}$ was increased significantly with increase nitrogen levels was reported by Khan et al. (2014). The interaction between plant spacing and nitrogen fertilization has no significant influence on number of leaves plant ${ }^{-1}$ at 30 DAT, at 45 DAT and at final harvest. At 30 DAT, numerically the highest number of leaves plant ${ }^{-1}$ (9.33) was obtained at spacing $35 \mathrm{~cm} \times 30 \mathrm{~cm}$ fertilized with $150 \mathrm{~kg} \mathrm{~N} \mathrm{ha}^{-1}$ and spacing $35 \mathrm{~cm} \times 30 \mathrm{~cm}$ along with $200 \mathrm{~kg} \mathrm{~N}^{-1}$ followed by spacing $35 \mathrm{~cm} \times 10 \mathrm{~cm}$ along with $200 \mathrm{~kg} \mathrm{~N} \mathrm{ha}^{-1}$ and the lowest number of leaves plant ${ }^{-1}$ (7.66) was obtained at spacing $35 \mathrm{~cm} \times 10 \mathrm{~cm}$ along with $150 \mathrm{~kg} \mathrm{~N} \mathrm{ha}^{-1}$ (Table 3). At 45 DAT, numerically the highest number of leaves plant $^{-1}$ (10.67) of Z. mays was obtained at plant spacing $35 \mathrm{~cm} \times$ $10 \mathrm{~cm}$ along with $200 \mathrm{~kg} \mathrm{~N} \mathrm{ha}^{-1}$ and spacing $35 \mathrm{~cm} \times 30 \mathrm{~cm}$ along with $200 \mathrm{~kg} \mathrm{~N} \mathrm{ha}^{-1}$ followed by spacing $35 \mathrm{~cm} \times 20 \mathrm{~cm}$ along with $200 \mathrm{~kg} \mathrm{~N} \mathrm{ha}^{-1}$ and the lowest number of leaves plant ${ }^{-1}$ (9.00) of Z. mays was obtained at spacing $35 \mathrm{~cm} \times 10 \mathrm{~cm}$ along with 150 $\mathrm{kg} \mathrm{N} \mathrm{ha}^{-1}$ (Table 3). At harvest, numerically the highest number of leaves plant ${ }^{-1}$ (12.33) of Z. mays was obtained at $35 \mathrm{~cm} \times 10$ $\mathrm{cm}$ spacing along with $200 \mathrm{~kg} \mathrm{~N} \mathrm{ha}^{-1}$ and spacing $35 \mathrm{~cm} \times 20 \mathrm{~cm}$ along with $200 \mathrm{~kg} \mathrm{~N}^{-1}$ followed by spacing $35 \mathrm{~cm} \times 30 \mathrm{~cm}$ along with $200 \mathrm{~kg} \mathrm{~N}^{-1}$ and the lowest number of leaves plant ${ }^{-1}$ (10.00) of Z. mays was obtained at spacing $35 \mathrm{~cm} \times 10 \mathrm{~cm}$ along with $100 \mathrm{~kg} \mathrm{~N} \mathrm{ha}^{-1}$ (Table 3).

\section{Leaf chlorophyll content (SPAD value)}

Chlorophyll content was significantly influenced by plant spacing. The highest chlorophyll content (37.14) of Z. mays was obtained at spacing $35 \mathrm{~cm} \times 30 \mathrm{~cm}$, which was statistically identical to $35 \mathrm{~cm} \times 20 \mathrm{~cm}$ spacing and the lowest chlorophyll content (34.16) of Z. mays was obtained at the spacing $35 \mathrm{~cm} \times$ $10 \mathrm{~cm}$ (Figure 1). Nitrogen fertilization has significant influence on chlorophyll content. The highest chlorophyll content (41.50) was obtained in $200 \mathrm{~kg} \mathrm{~N}^{-1}$ and the lowest chlorophyll content (32.27) of Z. mays was obtained from $100 \mathrm{~kg} \mathrm{~N} \mathrm{ha}^{-1}$, which was statistically identical to $150 \mathrm{~kg} \mathrm{~N}^{-1}$ (Figure 2). Leaf Chlorophyll Content was increased significantly with increase nitrogen levels was reported by Ullah et al. (2015). The interaction between plant spacing and nitrogen fertilization has significant influence on chlorophyll content. The highest chlorophyll content (45.30) of Z. mays was obtained at spacing $35 \mathrm{~cm} \times 10$ $\mathrm{cm}$ fertilized with $200 \mathrm{~kg} \mathrm{~N} \mathrm{ha}^{-1}$, which was statistically identical to spacing $35 \mathrm{~cm} \times 20 \mathrm{~cm}$ along with $100 \mathrm{~kg} \mathrm{~N} \mathrm{ha}{ }^{-1}, 35 \mathrm{~cm} \times 20$ $\mathrm{cm}$ along with $200 \mathrm{~kg} \mathrm{~N} \mathrm{ha}^{-1}, 35 \mathrm{~cm} \times 30 \mathrm{~cm}$ along with $100 \mathrm{~kg} \mathrm{~N}$ $\mathrm{ha}^{-1}, 35 \mathrm{~cm} \times 30 \mathrm{~cm}$ along with $150 \mathrm{~kg} \mathrm{~N} \mathrm{ha}^{-1}$ and $35 \mathrm{~cm} \times 30 \mathrm{~cm}$ along with $200 \mathrm{~kg} \mathrm{~N} \mathrm{ha}^{-1}$ and the lowest chlorophyll content (25.73) of Z. mays was obtained at spacing $35 \mathrm{~cm} \times 10 \mathrm{~cm}$ along with $100 \mathrm{~kg} \mathrm{~N} \mathrm{ha}^{-1}$, which was statistically identical to spacing $35 \mathrm{~cm} \times 10 \mathrm{~cm}$ along with $150 \mathrm{~kg} \mathrm{~N} \mathrm{ha}^{-1}, 35 \mathrm{~cm} \times 20 \mathrm{~cm}$ along with $100 \mathrm{~kg} \mathrm{~N} \mathrm{ha}^{-1}, 35 \mathrm{~cm} \times 20 \mathrm{~cm}$ along with $150 \mathrm{~kg} \mathrm{~N} \mathrm{ha}^{-1}, 35$ $\mathrm{cm} \times 30 \mathrm{~cm}$ along with $100 \mathrm{~kg} \mathrm{~N} \mathrm{ha}{ }^{-1}$ and $35 \mathrm{~cm} \times 30 \mathrm{~cm}$ along with $150 \mathrm{~kg} \mathrm{~N} \mathrm{ha}^{-1}$ (Figure 3). 




Figure 3. Effect of interaction between plant spacing and level of nitrogen $(\mathrm{kg}$ $\mathrm{ha}^{-1}$ ) on chlorophyll content of Z. mays as fodder crop.

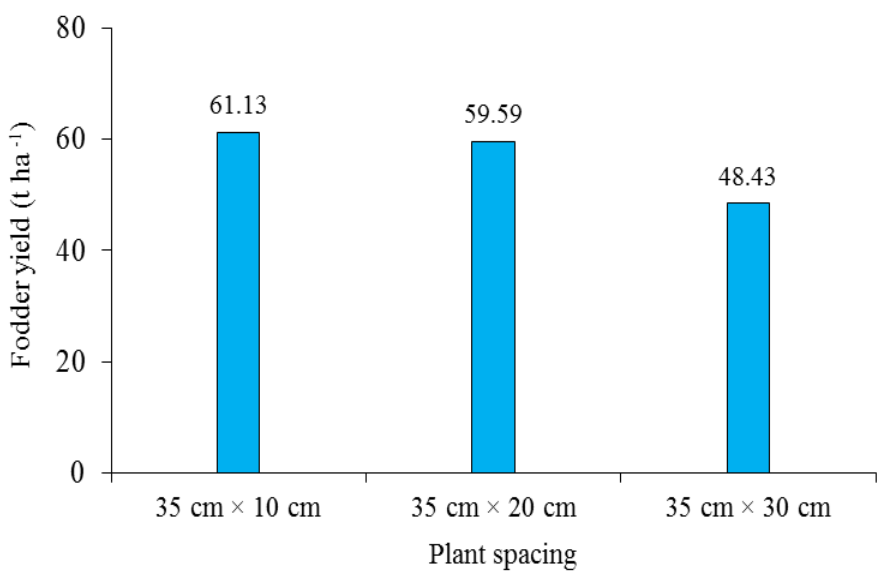

Figure 4. Effect of plant spacing on fodder yield of Z. mays.

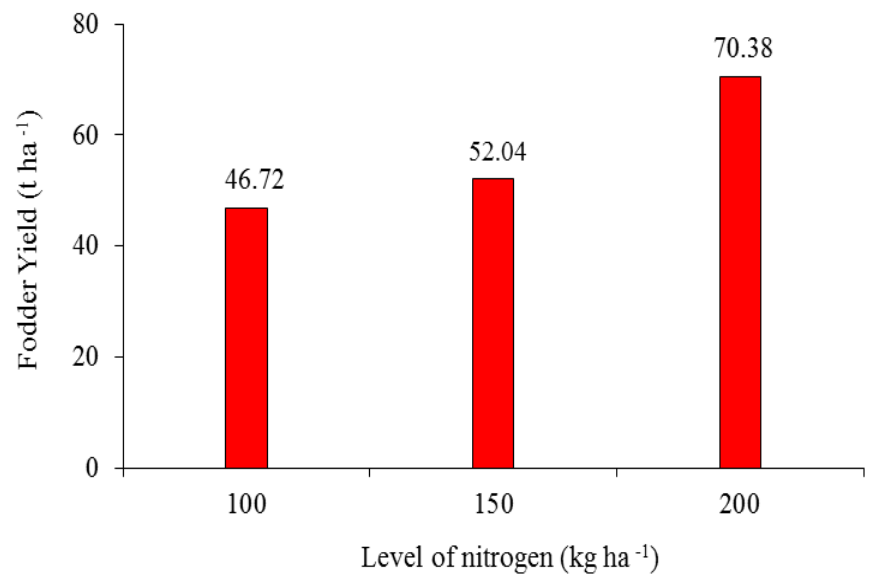

Figure 5. Effect of level of nitrogen on fodder yield of Z. mays.

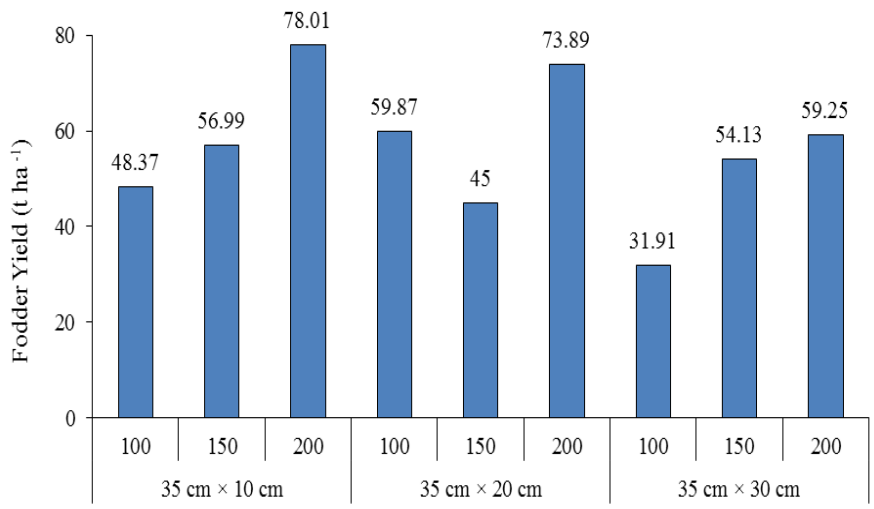

Interaction (Spacing $\times$ Nitrogen)

Figure 6. Effect of interaction between plant spacing and level of nitrogen $\left(\mathrm{kg} \mathrm{ha}^{-1}\right)$ on fodder yield of Z. mays.
Fodder yield of Z. mays

Fodder yield was significantly influenced by plant spacing. The highest fodder yield $\left(61.13 \mathrm{t} \mathrm{ha}^{-1}\right)$ of $Z$. mays was obtained at the plant spacing $35 \mathrm{~cm} \times 10 \mathrm{~cm}$ followed by spacing $35 \mathrm{~cm} \times 20 \mathrm{~cm}$ and the lowest fodder yield (48.43 $\mathrm{t}^{\text {ha }}{ }^{-1}$ ) of Z. mays was obtained at spacing $35 \mathrm{~cm} \times 30 \mathrm{~cm}$ (Figure 4). Nitrogen fertilization has significant influence on fodder yield. The highest fodder yield (70.38 $\mathrm{t} \mathrm{ha}^{-1}$ ) of Z. mays was obtained in $200 \mathrm{~kg} \mathrm{~N} \mathrm{ha}^{-1}$ followed by $150 \mathrm{~kg} \mathrm{~N}^{-1}$ and the lowest fodder yield $(46.72 \mathrm{t}$ $\mathrm{ha}^{-1}$ ) of Z. mays was obtained in $100 \mathrm{~kg} \mathrm{~N} \mathrm{ha}^{-1}$ (Figure 5). Similar results were reported by Khan et al. (2014), who reported that application of nitrogen fertilization significantly increased fodder yield of maize. The interaction between plant spacing and nitrogen fertilization has significant influence on fodder yield of Z. mays. The highest fodder yield $\left(78.01 \mathrm{t} \mathrm{ha}^{-1}\right)$ of Z. mays was obtained at plant spacing $35 \mathrm{~cm} \times 10 \mathrm{~cm}$ fertilized with 200 $\mathrm{kg} \mathrm{N} \mathrm{ha}^{-1}$, which was statistically identical to spacing $35 \mathrm{~cm} \times 20$ $\mathrm{cm}$ fertilized with $200 \mathrm{~kg} \mathrm{~N} \mathrm{ha-1}$ and the lowest fodder yield (31.91 $\mathrm{t} \mathrm{ha}^{-1}$ ) of Z. mays was obtained at spacing 35 $\mathrm{cm} \times 30 \mathrm{~cm}$ fertilized with $100 \mathrm{~kg} \mathrm{~N} \mathrm{ha}^{-1}$ (Figure 6).

\section{Conclusion}

Plant spacing and nitrogen fertilization has significant influence on vegetative growth and green fodder yield of maize. Results of the study revealed that the tallest plant, the highest number of leaves plant ${ }^{-1}$ at 45 DAT, the highest number of leaves plant ${ }^{-1}$ at harvest and the highest chlorophyll content of Z. mays were produced by $35 \mathrm{~cm} \times 10 \mathrm{~cm}$ plant spacing fertilized with $200 \mathrm{~kg}$ $\mathrm{N} \mathrm{ha}^{-1}$. The highest fodder yield of Z. mays was obtained in spacing $35 \mathrm{~cm} \times 10 \mathrm{~cm}$ fertilized with $200 \mathrm{~kg} \mathrm{~N} \mathrm{ha}^{-1}$, which was as good as $35 \mathrm{~cm} \times 20 \mathrm{~cm}$ spacing fertilized with $200 \mathrm{~kg} \mathrm{~N} \mathrm{ha}^{-1}$ while the lowest fodder yield of Z. mays was obtained at spacing $35 \mathrm{~cm} \times 30 \mathrm{~cm}$ along with $100 \mathrm{~kg} \mathrm{~N} \mathrm{ha}^{-1}$. Therefore, spacing 35 $\mathrm{cm} \times 10 \mathrm{~cm}$ along with $200 \mathrm{~kg} \mathrm{~N} \mathrm{ha}^{-1}$ appears as the promising practice of $Z$. mays cultivation in terms green fodder yield.

Open Access: This is an open access article published under the terms and conditions of Creative Commons AttributionNonCommercial 4.0 International License which permits noncommercial use, distribution, and reproduction in any medium, provided the original author(s) if the sources are credited.

\section{REFERENCES}

Gomez, K.A. and Gomez, A.A. (1984). Statistical Procedure for Agricultural Research-International Rice Research Institute Book, A Wiley Interscience, John Wiley and Sons Inc., New York, USA. pp. 680.

Haque, M.M., Hamid, A. and Bhuiyan, N.I. (2001). Nutrient uptake and productivity as affected by nitrogen and potassium application levels in maize/sweet potato intercropping system. Korean Journal of Crop Science, 46:1-5.

Khan, A., Munsif, F., Akhtar, K., Afridi, M.Z., Zahoor, Ahmad, Z., Fahad, S., Ullah, R., Khan, F.A. and Din, M. (2014). American Journal of Plant Sciences, 5: 23232329.

Lamana, M.C.L. (2007). Effect of spacing between plants on growth and forage yield of two maize (Zea mays L.) cultivars. Department of Agronomy, Faculty of Agriculture, University of Khartoum. pp. 12-18. 
Mandić, V., Simić, A., Tomić, Z., Krnjaja, V., Bijelić, Z., Marinkov, G. and Stojanović, L.J. (2013). Effect of drought and foliar fertilization on maize production. Proceedings of the 10th International Symposium Modern Trends in Livestock Production, Belgrade, Serbia, 2-4 October 2013, 416-429.

Paul, S.K., Paul, U., Sarkar, M.A.R. and Hossain, M.S. (2018). Yield and quality of tropical sugar beet as influenced by variety, spacing and fertilizer application. Sugar Tech, 20(2): 175-181, https://doi.org/10.1007/s12355-017-0545-3

Salam. M.A., Sarder, M.S.A., Ullah, M.J., Kawochar, M.A. and Islam, M.K. (2010). Effect of different spacing and levels of nitrogen fertilizer on the yield attributes and yield of hybrid maize. Journal of Experimental Biosciences, 1(2): 57-61.

Tajul, M.I., Alam, M.M., Hossain, S.M.M., Naher, K., Rafii, M.Y. and Latif, M.A. (2013). Influence of plant population and nitrogen fertilizer at various levels on growth and growth efficiency of maize. The Scientific World Journal, 2013: 1-9, https://dx.doi.org/10.1155/2013/193018
Ullah, M.I., Khakwani, A.A., Sadiq, M., Awan, I., Munir, M. and Ghazanfarullah (2015). Effects of nitrogen fertilization rates on growth, quality and economic return of fodder maize (Zea mays L.). Sarhad Journal of Agriculture, 31(1): 45-52.

UNDP and FAO (1988). Land Resources Appraisal of Bangladesh for Agricultural Development. Report 2. Agroecological Regions of Bangladesh. United Nations Development Programme and Food and Agriculture Organization. pp. 212-221.

Verma, N.J. (2011). Integrated nutrient management in winter maize (Zea mays L.) sown at different dates. Journal of Plant Breeding and Crop Science, 3(8): 161-167.

Zamir, M.S.I., Ahmad, A.H., Javeed, M.R. and Latif, T. (2011). Growth and yield behaviour of two maize hybrids (Zea mays L.) towards different plant spacing. Cercetări Agronomice în Moldova. 14(2): 33-40.

Zhu, J., Tremblay, N. and Liang, Y. (2012). Comparing SPAD and at LEAF values for chlorophyll assessment in crop species. Canadian Journal of Soil Science, 92: 645-648. 